\title{
Paranasal Sinus Squamous Cell Carcinoma
}

National Cancer Institute

\section{Source}

National Cancer Institute. Paranasal Sinus Squamous Cell Carcinoma. NCI Thesaurus.

Code C8193.

A squamous cell carcinoma that arises from the mucosal epithelial surface of the ethmoid, frontal, maxillary, or sphenoid sinus. Patients may present with nasal fullness, obstruction, and/or epistaxis. 